metodologia. Mimo wyznaczenia nowych tropów w analizowanym zagadnieniu autor jest świadomy potrzeby dalszych badań, których efekty moga zwiększyć stan aktualnie posiadanej wiedzy na temat tego tragicznego wydarzenia w dziejach miasta. I choć w niektórych momentach recenzowana książka mogłaby być nieco bardziej rozbudowana (np. w kwestii biografii Porcella i jego dzieła), wydaje się, że autorowi zależało na syntetycznym ujęciu tematu i wierności rygorowi naukowemu, który nie pozostawia miejsca na spekulacje, czasami atrakcyjne i kuszące, ale jednak niewnoszące niczego nowego i wartościowego do nauki. W tym sensie syntetyczność i zwięzłość książki przesądzają o jej naukowości.

Filip Kubiaczyk (Poznań-Gniezno) Nr ORCID: 0000-0003-4124-6480

\title{
Katarzyna Kuras, Dwór królowej Marii Leszczyńskiej. Ludzie, pieniądze i wptywy, Towarzystwo Wydawnicze „Historia Iagellonica”, Kraków 2018, ss. 337
}

Tematem tej interesującej książki jest szeroko pojęte funkcjonowanie 1 dworu królowej francuskiej Marii Leszczyńskiej, córki niefortunnego polskiego monarchy Stanisława Leszczyńskiego. Przy tej okazji autorka 
musiała też zająć się bliżej postacią królowej Marii, której małżeństwo z Ludwikiem XV wywołało swego rodzaju sensację i obrosło różnorodnymi interpretacjami. Temat ten jest oczywiście ważny dla historii politycznej, ale też dla historii społecznej, historii kultury, życia codziennego, a nawet sztuki. O jego aktualności może świadczyć niedawna, imponująca wystawa poświęcona wersalskiemu dworowi Marii Leszczyńskiej zorganizowana w latach 2013-2014 przez Zamek Królewski w Warszawie i Pałac w Wersalu.

Książka Katarzyny Kuras mieści się w głównym nurcie studiów nad elitami władzy, nawiązuje przy tym do francuskiej szkoły „Annales”, wzbogaconych o elementy socjologii. W jakiejś mierze sięga także do modeli wprowadzonych do polskiej historiografii przez Antoniego Mączaka. Autorka zwraca jednak uwagę również na nowsze podejścia do tej problematyki (zwłaszcza w literaturze amerykańskiej) podkreślające konieczność oparcia pogłębionych studiów nad składem, strukturą i funkcjonowaniem dworów europejskich nie tylko na teoretycznych założeniach, ale przede wszystkim na wyczerpujących kwerendach źródłowych. Wskazuje też na pojawienie się ostatnio prób prozopograficznego ujęcia środowisk dworskich. Autorka niejako nawiązuje do tych nowszych założeń, zapowiadając we Wstępie, że chce przedstawić w swojej książce „biografię zbiorowości”, ludzi otaczających przez „kilkadziesiąt lat [...] królową Francji” (s. 21). Powiedziałbym jednak, że niektóre rozważania autorki (np. na s. 24-26) mają, w ślad za nowszą literaturą, charakter nieco zbyt teoretyczny.

Praca Katarzyny Kuras stanowi w pewnej mierze biografię Marii Leszczyńskiej. Autorka z powodzeniem wykorzystuje metody stosowane w naukach pokrewnych: antropologii, psychologii społecznej czy socjologii. Powołuje się też na podobne badania nad dworami polskich królowych, szczególnie Barbary Radziwiłłówny. Można tu było jeszcze sięgnąć do, dość tradycyjnej zresztą, monografii Agnieszki Marchwińskiej Królewskie dwory żon Zygmunta Augusta (Toruń 2008). Katarzyna Kuras bardzo dobrze orientuje się w obecnym stanie badań nad postacią królowej Marii Leszczyńskiej, tak polskich, jak i francuskich, szczegółowo omawia też te prace we Wstępie. Dodałbym w tym miejscu krótką wzmiankę o książce Aurelii Wyleżyńskiej Marja Leszczyńska na dworze wersalskim. Praca ta, obecnie oczywiście przestarzała, miała jednak przed wojną dwa wydania (w 1923 i 1935 r.), a oparta jest na dawnej literaturze i pamiętnikach. Inna rzecz, że 
dr Katarzyna Kuras zna tę książkę i w swojej rozprawie nieraz się na nią powołuje. Omawiając stan badań, warto byłoby ponadto szerzej wspomnieć o znakomitej polsko-francuskiej wystawie zatytułowanej „Wersal Marii Leszczyńskiej. Sztuka dworska we Francji XVIII wieku” („Le Versailles de Marie Leszczyńska. L'art à la cour de France au XVIII siècle"), którą można było obejrzeć na Zamku Królewskim w Warszawie od września 2013 do stycznia $2014 \mathrm{r}$. W wydanym wówczas obszernym katalogu (Warszawa 2013) znalazły się też interesujące eseje poświęcone m.in. ceremoniałowi na dworze polskim i francuskim w dobie nowożytnej, pobytowi Marii Leszczyńskiej na dworze wersalskim i wyposażeniu apartamentów tej królowej. Wystawa ta wzbudziła spore zainteresowanie i przypomniała szerszej publiczności postać tej Polki na francuskim tronie. Autorka odwołuje się zresztą w tekście swej rozprawy do tych esejów.

Podstawa źródłowa monografii dr Katarzyny Kuras jest niezwykle różnorodna. Obok pamiętników (zwłaszcza wydanych drukiem 17 tomów dzienników diuka Charles’a-Phillipe’a de Luynes’a, zaufanej osoby królowej Marii Leszczyńskiej), korespondencji królowej (przeważnie także opublikowanej drukiem) zasadnicze znaczenie mają publikowane ówcześnie (do 1749 r.) spisy (rejestry) dworzan i urzędników otaczających króla i jego rodzinę. Autorka, pragnąc uzupełnić luki w tych wydawnictwach, sięgnęła do przechowywanych w Archives Nationales w Paryżu rękopiśmiennych spisów dworzan królowej z lat 1725-1767 (zawarte tam są też informacje dotyczące spraw finansowych). Przeprowadziła ponadto kwerendy archiwalne w pozostałych zespołach tegoż archiwum i w innych archiwach oraz bibliotekach, zwłaszcza francuskich. Wykorzystała również zachowaną w kopiach korespondencję króla Stanisława Leszczyńskiego ze swoją córką, królową francuską. Nie ulega wątpliwości, że zarówno znajomość szeroko pojętej literatury dotyczącej funkcjonowania dworów europejskich władców (ze szczególnym uwzględnieniem Francji), jak i oparcie się na właściwie pełnej bazie źródłowej (w dużej mierze dotąd niewykorzystywanej) sprawiło, że recenzowana monografia stanowi wzorowy przykład właściwych poszukiwań heurystycznych.

Konstrukcja rozprawy ewidentnie wynika z teoretycznych założeń szczegółowo omówionych we Wstępie. Rozdział pierwszy stanowi zwięzłą próbę biografii Marii Leszczyńskiej. Autorka wyraźnie koncentruje się na 
niektórych, szczególnie istotnych aspektach, tj. na ukazaniu królowej jako małżonki Ludwika XV, matki następcy tronu (delfina), na jej życiu codziennym na wersalskim dworze, wreszcie na scharakteryzowaniu jej najbliższych francuskich przyjaciół. Autorka w pełni wykorzystuje tu ustalenia dotychczasowej literatury, uzupełniając je o dodatkowe informacje zaczerpnięte z francuskich archiwów. Wyraźniej natomiast można było zaakcentować tezę postawioną swego czasu przez Emanuela Rostworowskiego (Jeszcze o ślubie Marii Leszczyńskiej i polskiej koronie, w: E. Rostworowski, Legendy i fakty XVIII w., Warszawa 1963, s. 9-65), że małżeństwo Marii Leszczyńskiej z Ludwikiem XV miało charakter polityczny i wiązało się z planami stworzenia tzw. bariery wschodniej skierowanej głównie przeciw Habsburgom. Można też było dodać, że królowa Maria Leszczyńska przejęła po ojcu nie tylko zamiłowanie do muzyki (już w 1708 r. Stanisław Leszczyński sprowadził na swój dwór muzyków z kapeli Augusta II), ale i do gry w karty (później Ludwik XV musiał spłacać długi karciane swej małżonki, o czym autorka kilkakrotnie wspomina). Interesujące są uwagi Katarzyny Kuras dotyczące kręgu przyjaciół królowej, form spędzania wolnego czasu i formacji intelektualnej ludzi z tego kręgu. Autorka sugeruje, że związki personalne między prywatnym kręgiem królowej a paryskimi salonami były ściślejsze, niż to się przypuszcza, i można tu mówić raczej o korelacji niż rywalizacji. Podziela przy tym opinię występującą w najnowszej literaturze francuskiej, że model prywatności stworzony przez Marię Leszczyńską mógł być atrakcyjny dla samotnych kobiet $\mathrm{z}$ arystokracji.

Rozdział drugi poświęcony hierarchii i organizacji dworu królowej Marii Leszczyńskiej przedstawia, w dość tradycyjny sposób, strukturę poszczególnych jednostek organizacyjnych funkcjonujących na tym dworze. Poprzedzone to jest wstępnym szkicem ukazującym kształtowanie się tej instytucji w historycznej perspektywie, począwszy od XVI w. Dla polskiego czytelnika może być zaskoczeniem, że liczebność dworu (maison) królowej Marii Leszczyńskiej wynosiła ok. 430-450 osób, podczas gdy ścisły dwór Ludwika XV przekraczał 2000 osób. Dla porównania można podać, że dwory polskich królowych w XVI w. liczyły niewiele ponad 100 osób (A. Marchwińska, op. cit., s. 159). Korzystając z drukowanych i rękopiśmiennych wykazów dworzan (służby) dr Katarzyna Kuras szczegółowo przedstawiła liczbę urzędników dworu królowej i funkcje sprawowane 
przez poszczególne osoby. W następnych dwóch rozdziałach omówiono sprawy rekrutacji dworzan, czynniki i przebieg ich karier, ich wynagrodzenie (nie tylko pieniężne), wreszcie ogólne zasady finansowania dworu Marii Leszczyńskiej. Warto zaznaczyć, że gaże (pensje) dworzan miały im niejako rekompensować wydatki związane z zakupem urzędu. Sprzedawalność urzędów była zresztą cechą typową nie tylko dla biurokracji francuskiej. System wynagradzania dworzan był przy tym bardzo skomplikowany i autorka musiała tej problematyce poświęcić w swej pracy sporo uwagi.

Najciekawszą część rozprawy stanowią, moim zdaniem, rozdziały piąty i szósty. Autorka odchodzi tu od prozopografii i podejmuje udaną próbę zastosowania metod zaczerpniętych z psychologii społecznej i antropologii kultury. Odnosząc się do obowiązujących wówczas norm i wzorców postępowania, daje interesujący i wnikliwy obraz stosunków panujących na dworze królowej Marii Leszczyńskiej, wygórowanych ambicji poszczególnych dworzan, wzajemnych intryg i konfliktów, ujawniających się mimo obowiązywania sztywnego ceremoniału i zasad przestrzegania dworskiej etykiety. Autorka przytacza bardzo wiele konkretnych przykładów na poparcie swoich twierdzeń. Z lektury rozdziału piątego dotyczącego wartości i relacji między dworzanami można wysnuć wniosek, że dominowała wśród nich ciągła rywalizacja, a przypadki współpracy i zawierania kompromisów wzbudzały co najmniej zdziwienie. Nakładały się na to wszystko liczne spory kompetencyjne. Na tym tle Katarzyna Kuras wysoko ocenia postępowanie królowej, która próbowała łagodzić konflikty i integrować wokół siebie środowisko dworskie. Było to o tyle trudne, że niektóre z dam dworu królowej były jednocześnie faworytami jej męża Ludwika XV.

Próbę podsumowania wcześniejszych analiz stanowi rozdział szósty poświęcony ocenie pozycji królowej Marii Leszczyńskiej w ówczesnej Francji oraz wpływów jej i jej dworzan na życie dworskie, a także na sprawy polityczne. Autorka słusznie przypomina przy tym, że we Francji królowa była tylko małżonką króla i „nie posiadała realnej władzy” (s. 254). Podważa w związku z tym opinie pojawiające się w dawniejszej historiografii francuskiej, jakoby Maria Leszczyńska stała na czele tzw. koterii dewotów, wspierającej jezuitów i przeciwstawiającej się opozycji parlamentów. Wskazuje, że już współcześni realnie oceniali rzeczywiste wpływy królowej na dworze francuskim jako nieznaczne. Zwraca też uwagę, że z czasem na dworze 
powstał system bliskiej współpracy Ludwika XV z kolejnymi faworytami, co „ostatecznie wyeliminowało królową” (s. 255) z ingerowania w sprawy państwowe. Maria Leszczyńska mogła w związku z tym przejawiać aktywność jedynie w niektórych, ,akceptowanych przez monarchę”, sferach życia (s. 255). Autorka przytacza też przykłady ewidentnych niezręczności popełnianych przez królową, zwłaszcza w początkowym okresie swego małżeństwa, co m.in. skutkowało nieufnością ze strony króla i niechęcią ze strony wpływowego ministra, kardynała André-Hercule’a de Fleury. W odrębnym podrozdziale autorka podważa przekonanie o istnieniu na dworze francuskim jednolitej „koterii dewotów” skupionej wokół Marii Leszczyńskiej. Stawia tezę, że większą aktywnością w tej grupie wyróżniały się raczej królewskie dzieci, tj. delfin Ludwik i jego siostry. W pewnej mierze zgadza się też z jedną z ówczesnych opinii sugerujących, że na dworze zajmowano się przede wszystkim wewnętrznymi intrygami. Katarzyna Kuras próbuje przy tym dokonać oceny skuteczności protekcji królowej Marii dla jej przyjaciół i dworzan. Wypada zgodzić się ze zdaniem autorki, że sukcesy uzyskiwała Leszczyńska raczej tylko w drobnych sprawach. Rozpatrując zmieniające się koterie na dworze królowej i rywalizację poszczególnych dworzan i dam dworu, autorka dochodzi do pozornie zaskakującego wniosku, że najbardziej wpływową osobą z otoczenia Marii Leszczyńskiej stała się pani Jeanne-Antoinette Poisson, markiza de Pompadour. To korzystając z jej pośrednictwa, królowa zabiegała o załatwienie określonych, raczej drobnych, spraw u Ludwika XV. Najlepiej chyba oddaje to rzeczywiste możliwości Marii Leszczyńskiej. Wypada całkowicie przyznać rację Katarzynie Kuras, która stwierdza, że królowa „doskonale wypełniała swe funkcje jako małżonka królewska”, będąc "monarchinią w pełni pogodzoną ze swoją pozycją”, „bardziej marionetką niż inicjatorką” (s. 283). Dla dworzan i sług królowej pełnienie funkcji na jej dworze było natomiast źródłem prestiżu i przekonania, że uczestnictwo w dworskich ceremoniach (teatrze władzy) zapewnia im odpowiednio wysoką pozycję w ówczesnym stanowym społeczeństwie.

Katarzyna Kuras wykazała się w recenzowanej rozprawie znakomitą orientacją w literaturze przedmiotu (zwłaszcza najnowszej), skrupulatnością przy wykorzystywaniu różnorodnych źródeł (relacji pamiętnikarskich, ówczesnych druków i archiwaliów), a także umiejętnością analizy i wyciągania interesujących wniosków. Pod względem metodologicznym praca ta 
jest $\mathrm{w}$ polskiej historiografii niewątpliwie nowatorska. Traktuje bowiem dwór jako pewną skostniałą strukturę, o której funkcjonowaniu decydują przede wszystkim ceremoniał i sztywne reguły. Praca ta przynosi ponadto bardzo dużo cennego materiału biograficznego (prozopograficznego), dając wgląd w skład dworu królowej.

Jerzy Dygdata (Toruń)

Nr ORCID: 0000-0002-9804-6845

\title{
Wojciech Szafrański, Józef Weyssenhoff - polityk, prawnik, legislator czasów oświecenia, Wydawnictwo Naukowe UAM, Poznań 2017, ss. 574
}

\begin{abstract}
utor recenzowanej monografii zajmował się już postacią Józefa WeysIsenhoffa, ale nie tyle „w wymiarze biograficznym”, lecz także w związ$\mathrm{ku} \mathrm{z}$ jego papierami istotnymi dla dziejów reformy humanitarnej prawa karnego w Rzeczypospolitej polsko-litewskiej pod koniec XVIII w. ${ }^{1}$ Obecnie, po wielu latach poszukiwań źródłowych (a jest to w tym przypadku
\end{abstract}

1 Por. tegoż autora: Kodeks Stanistawa Augusta, Poznań 2007. 